\title{
Epstein-Barr Virus Infection Related to Low White Blood Cell Count in Cancer Patients Receiving Chemotherapy in Al-Najaf Governorate/Iraq
}

\author{
Thikra Abdullah Mahmood ${ }^{1 *}(\mathbb{D})$, Heider Hemeed Abbas $^{2}(\mathbb{D}$ and \\ Saif Jabbar Yasir ${ }^{3}$ iD \\ ${ }^{1}$ Department of Community Medicine, College of Medicine, University of Kufa, Kufa, Iraq. ${ }^{2}$ Basic Medical \\ Sciences, University of Babylon, Babil, Iraq. ${ }^{3}$ Department of Medical Microbiology, Faculty of Medicine, \\ University of Kufa, Kufa, Iraq.
}

\begin{abstract}
Epstein-Barr virus (EBV) plays the most important role in various types of human cancers. Patients receiving chemotherapy have low white blood cell (WBC) counts that elevate the risk of infection and is the first public health priority in Iraq. WBCs are capable of tumor destruction and aid in combatting infection; they also promote tumor growth, metastasis and chemotherapy resistance. Low WBC count makes the body more predisposed to infection. Our study sought to investigate the relationship between low WBC count and EBV infection in cancer patients. A cross-sectional study was performed using 120 samples obtained from cancer patients, who had a low WBC count and were receiving chemotherapy. The study included samples from 60 males and 60 females aged between 7 and 80 years from Najaf / Iraq. Among the different cancer types, breast cancer cases were high (24 patients; 20\%); additionally, a high number of cancer patients $\left(52 ; 43.3 \%\right.$ ) also had a low WBC count ( $\leq 2$ to $\geq 4$ in $10^{9} / \mathrm{L}$ of cells). There were no significant differences in the serological detection of positive cases for viral capsid protein IgM and EBNA-1 and EBNA-2 nuclear genes $(P>0.05)$ between the cancer patients of different age groups and genders. EBV infection is associated with a low WBC count in cancer patients receiving chemotherapy. No significant differences for patients was observed with respect to age and gender.
\end{abstract}

Keywords: Epstein-Barr virus infection, Serology, Immunoblotting, Avidity IgG, Epstein-Barr virus-DNA

\footnotetext{
*Correspondence: thakraas@gmail.com

(Received: December 14, 2019; accepted: June 24, 2020)

Citation: Yasir SJ, Mahmood TA, Abbas HH. Epstein-Barr Virus Infection Related to Low White Blood Cell Count in Cancer Patients Receiving Chemotherapy in Al-Najaf Governorate/Iraq. J Pure App/ Microbiol. 2020;14(2):1609-1617. doi: 10.22207/JPAM.14.2.59

(C) The Author(s) 2020. Open Access. This article is distributed under the terms of the Creative Commons Attribution 4.0 International License which permits unrestricted use, sharing, distribution, and reproduction in any medium, provided you give appropriate credit to the original author(s) and the source, provide a link to the Creative Commons license, and indicate if changes were made.
} 


\section{INTRODUCTION}

Epstein-Barr virus (EBV) belongs to the gammaherpesvirus subfamily that exclusively infects humans ${ }^{1-3}$. Various human tumors, such as the nasopharyngeal carcinoma and Burkett's lymphoma (BL) are related to the actions of the EBV ${ }^{4,5}$. Viral nuclear antigens (EBNAs) and 3 latent membrane proteins are expressed in the target cells during the latent stage of infection. EBNA is a complex of at least 6 proteins ${ }^{6}$. EBNA-1 is responsible for the replication of EBV nucleic acids in the infected cells ${ }^{7}$. EBNA-2 has a role in $B$ lymphocyte growth transformation, a function which is closely interrelated to transactivation of viral and cellular gene expression ${ }^{8}$.

The normal range for white blood cell (WBC) counts varies with age and pregnancy. Healthy childhood to reach adult levels of 4,500 to $11,000 / \mathrm{mm}^{3}$ (4.5 to $11.0 \times 10^{9} / \mathrm{L} ; 95 \%$ confidence interval (C.I.) $)^{9}$. The life cycle of WBC includes differentiation and development, loading migration within the vascular spaces of the bone marrow, and migration to tissues ${ }^{10}$. Following maturation, $80-90 \%$ of WBCs remain in the bone marrow for storage. This great back upper mist for a rapid increase in the circulating WBC count within hours. A relatively small pool (2-3\%) of WBC circulate liberally in the peripheral blood ${ }^{11,12}$, the rest settle along the spleen or the margins of the walls of blood vessels. Majority of the life span of leukocytes is spent in storage. Notably, once a leukocyte is released into circulation and peripheral tissues, its life span ranges from 2-16 days depending on the cell type ${ }^{13}$.

The different types of WBCs are associated with a variety of diseases including hypersensitivity, tuberculosis, fungal infections, EBV infection, protozoa infections, leukopenia, Rickettsia, whooping cough, and acute or chronic leukemia ${ }^{14,15}$. Numerous tumors may stimulate the granulocytes-macrophage or spinal cord ${ }^{16}$. Laboratory analysis can aid in diagnosing previous and/or recent EBV infections by examining the presence of antibodies associated with the resulting EBV antigens ${ }^{17}$. This includes the detection of IgG antibodies against the viral capsule antigen (VCA), which appears at the time of onset of clinical symptoms of acute infection and remains positive for life. The anti-VCA IgM antibodies appear at the same time as the anti-
VCA IgG but usually disappear within a few weeks; notably, anti-VCA IgM can persist for several months following infection in some cases ${ }^{18,19}$. Early antigen-EA and EBV nuclear antigen-EBNA ${ }^{20}$. Apart from detecting past and present viral infections, laboratory analysis can also help in deciphering if an individual is predisposed to viral infections ${ }^{21}$.

WBCs are produced in the bone marrow and have a rapid growth, that is very sensitive to the effects of chemotherapy. Toxic effect of chemotherapy on the bone marrow may cause a decrease in the WBC count; certain medications can cause defects in the bone marrow as well ${ }^{22}$. Chemotherapy also destroys numerous cells of the bone marrow ${ }^{23}$. A decrease in circulating WBCs, with a total count that is less than $3.0 \times$ $10^{9} / L$, is referred to as leukopenia ${ }^{25}$. WBCs serve as protection against bacterial and viral infections as well as other diseases. Hence, leukopenia is associated with a greater risk of infection when compared with individuals who have normal WBC counts ${ }^{24}$. Notably, not all cancer patients undergoing chemotherapy suffer from leukopenia.

Various techniques have been utilized in detecting EBV nucleic acids and measuring its DNA load ${ }^{26}$. PCR and RT-PCR have been applied to differences in specificity and sensitivity ${ }^{27}$. Real-Time PCR was very advantageous for confirming infection status, particularly of immunocompromised patients ${ }^{28,29}$, as their viral load is higher than that of healthy and carrier individuals ${ }^{30}$. The viral load declines following therapy ${ }^{31}$. A search for EBV nucleic acid is beneficial in EBV-related tumor patients, who show low blood levels for the virus because of the bloodbrain barrier ${ }^{30,32}$. EBV nucleic acid from apoptotic tumor cells have been identified in the plasma, serum $^{33,34}$, and latently-infected tumor cells ${ }^{35}$.

This research is aimed at identifying Epstein-Barr virus in cancer patients receiving chemotherapy, and subsequently determining the white blood cell counts of the patients based on age and genders.

\section{MATERIALS AND METHODS}

In this study, 120 cancer patients receiving chemotherapy were recruited. The patients suffered with various types of cancers including, 24 breast cancer, 19 leukemia, 18 lymphoma, 10 lung cancer, 10 colorectal cancer, 
7 oropharyngeal cancer, 8 hepatocellular (liver) cancer, 5 bladder cancer, 5 brain cancer, 5 ovarian cancer, and 10 rare types of cancer cases. The age group of patients ranged between 25 and 64 years old. Blood samples were collected from patients during the period between October, 2018 and September, 2019. Samples were taken from the Central Euphrates Hospital oncology and cancer in Kufa, Al-Najaf province/Iraq. All official approvals were obtained from the hospital administration and participating patients after informing them of the purpose of the research. Patients were excluded if they were pregnant, had a newborn, underwent splenectomy, smoked or were taking medications.

\section{Study design}

A cross- sectional study was performed, wherein the sample size was calculated using the equation of the study type.

\section{Data collection}

To obtain the necessary data, $5 \mathrm{ml}$ of blood was withdrawn from the cancer patients. The blood samples were divided into two parts. The first portion was used for conducting a serological examination by separating out the serum from the sediment by centrifugation. Conversely, the second part was placed in EDTA tubes to conduct molecular diagnosis and determine the WBC count. A complete blood count (CBC) test with a peripheral smear may supply useful information, such as WBC maturity, type, and uniformity.

\section{Techniques}

\section{Viral capsid proteins detection}

All laboratory diagnoses were performed using each of the study sample. The diagnoses required the use of EBV-VCA IgM, VCA IgG, and EBV-1 antigen cortical antigens to determine previous or recent infections. VCA IgM is required to test the semi-automatic ELISA test group (DIESSE ${ }^{\circledR}$, Germany) to assess positive and negative detection of VCA IgM and IgG antibodies in the 120 serum samples that were collected from male $(n=60)$ and female $(n=60)$ cancer patients receiving chemotherapy in the Al-Najaf province. It appears that the anti-VCA IgM antibodies present at the time of acute EBV infection usually disappear within 4-6 weeks. Anti-VCA IgG was used to investigate the duration of a chronic EBV infection; anti-VCA IgG levels peak at 2-4 weeks after the onset of the disease, decreases slightly and then persists for the rest of the person's life. Patients were ready for EBV infection if they did not have VCA antibodies ${ }^{38}$. Clinical outcomes of infectious mononucleosis infection were tracked in conjunction with the emergence of anti-VCA IgM and IgG antibodies. However, an unsTable antibody pattern was regarded as an early symptom of EBV infection $^{39}$.

\section{EBNA detection \\ DNA extraction}

DNA specimens in whole blood samples were collected from patients undergoing chemotherapy and were extracted using a kit (Roche Diagnostics Gmb H, Mannheim, Germany) as previously reported ${ }^{40,41}$.

Amplification of viral DNA

PCR was carried out on a 3Prime Thermal Cycler, Techno Thermo cycler.

PCR cycles were performed as follows: 1 ) initial denaturation at $95^{\circ} \mathrm{C}$ for $5 \mathrm{~min}, 2$ ) 35 cycles of denaturation at $95^{\circ} \mathrm{C}$ for $45 \mathrm{~s}$ each, 3) annealing at $\left.56^{\circ} \mathrm{C}, 4\right)$ second annealing step at $72^{\circ} \mathrm{C}$ for 45 $\mathrm{s}$ and 5) elongation at $72^{\circ} \mathrm{C}$ for $1 \mathrm{~min}$. Finally, following a $10 \mathrm{~min}$ elongation step, the samples were cooled to $4^{\circ} \mathrm{C}$ and visualized on a $2 \%(w / v)$ agarose gel $\left.\right|^{42,43}$.

\section{Data analysis}

Statistical analysis was performed using the DNA Star software (version 10.0). A chisquared $\left(X^{2}\right)$ test was performed to define the distribution of EBV in patients. Significance was set at $P$ value $<0.05$. Statistical analyses were performed using SPSS 22.

\section{Constant}

The study was approved by the Medical Ethics Committee at the Medical faculty/University of Kufa.

\section{RESULTS}

The population distribution of the 120 cancer patients receiving chemotherapy in the Al-Najaf Governorate was determined. Among the 120 patients, 30 patients were $7-25$ years old (25\%); 27 patients were $26-44$ years old $(22.5 \%)$; 35 patients were $45-63$ years old $(29.2 \%)$ and 28 patients were $64-82$ years old or older (23.3\%) (Table 1). Cancer patients were found to be most commonly aged between 45 and 63 years old $(29.2 \%)$ for both males and females, as shown in Table 2. 
Table 1. The sequence of the primers (Synthesized by Bioneer)

\begin{tabular}{|c|c|c|c|}
\hline $\begin{array}{l}\text { Name of } \\
\text { primer } \\
\text { size }(b p)\end{array}$ & $\begin{array}{l}\text { Sequence }\left(5^{\prime}-3^{\prime}\right)(F: \text { Forward, } \\
\text { R: Reverse) }\end{array}$ & $\begin{array}{l}\text { Analyzed } \\
\text { region(B95-8 } \\
\text { coordinates) }\end{array}$ & Product \\
\hline EBNA-1 $\mathrm{F}$ & TGATAACCATGGACGAGGAC & 108 057-108 076 & 139 \\
\hline EBNA-1 $R$ & GCAGCCAATGCAACTTGGAC & & \\
\hline EBNA-2 F & AGGCTGCCCACC CTG AGGAT & 108 176-108 195 & 168 \\
\hline EBNA-2 R & 5-GCCACCTGGCAGCCCTAAAG & & \\
\hline
\end{tabular}

Table 2. Distribution of patients with cancer $(n=120)$ by age group

\begin{tabular}{lcc}
\hline $\begin{array}{l}\text { Age groups } \\
\text { per years }\end{array}$ & $\begin{array}{c}\text { No. } \\
\text { of cases }\end{array}$ & $\begin{array}{c}\text { Percentage } \\
\%\end{array}$ \\
\hline $7-25$ & 30 & 25.0 \\
$26-44$ & 27 & 22.5 \\
$45-63$ & 35 & 29.2 \\
$64-82$ & 28 & 23.3 \\
Total & 120 & 100 \\
\hline
\end{tabular}

Table 3 shows the distribution of patients based on the cancer type. The most common cancer type with a high percentage occurrence was determined to be breast cancer (20\%) in the city. This was followed by the moderately occurring leukemia (15\%), lymphoma (15\%), lung cancer $(8.3 \%)$ and colorectal cancer $(8.3 \%)$. The less common cancers included bladder, brain and ovarian cancers ( $4.2 \%$ each).

Table 3. Distribution of patients with types of cancer $(n=120)$ from male and female

\begin{tabular}{lcc}
\hline \multicolumn{3}{c}{ Parameters } \\
\hline Type of cancer & No. of cases & (\%) \\
\hline Breast cancer & 24 & 20 \\
Leukemia & 19 & 15.8 \\
Lymphoma & 18 & 15 \\
Lung cancer & 10 & 8.3 \\
Colorectal cancer & 10 & 8.3 \\
Oropharyngeal & 7 & 5.8 \\
cancer & & \\
Hepatocellular & 8 & 6.7 \\
(Liver) Cancer & & \\
Bladder cancer & 5 & 4.2 \\
Brain cancer & 5 & 4.2 \\
Ovarian Cancer & 5 & 4.2 \\
Rare types of cancer & 10 & 8.3 \\
Total & 120 & 100
\end{tabular}

The distribution of cancer patients on the basis of WBC count is shown in Table 4. At 95\% C.I., the WBC count (in $10^{9} / \mathrm{L}$ cells) was normal or more specifically equal to or greater than 4 in $43.3 \%$ of the patients. Additionally, 31.7\% and 25\% of patients had a WBC count (in $10^{9} / \mathrm{L}$ cells) of $2-3$ and less than or equal to 2 , respectively.

\section{Serological determination}

EBV VCA IgM were used to detect any previous or recent EBV infection in female patients. They were required to conduct a serological assay to determine if the patients were positive or negative for the anti-VCA IgM. The sera of 60 female cancer patients receiving chemotherapy were collected. The coefficients of variation for VCA IgM were $33.3 \%, 46.2 \%, 44.4 \%$, and $42.8 \%$ for patients aged 7-25, 26-44, 45-63 and 64-82 years, respectively. No significant differences were observed between the different age groups and the coefficients of variation for VCA IgM in females $(P \geq 0.05)$, as shown in Table 5 .

EBV VCA IgM was required to conduct an anti-VCA IgM ELISA to determine whether male cancer patients had been recently infected with EBV by assessing if they were positive for the anti-VCA IgM. The sera of 60 male cancer patients receiving chemotherapy were utilized. The coefficients of variation for the VCA IgM assay

Table 4. Distribution of patients cancer by count of white blood cells (WBC)

\begin{tabular}{lcc}
\hline $\begin{array}{l}\text { Count of } \\
\text { WBC }\left(10^{9} / \mathrm{L}\right.\end{array}$ & $\begin{array}{c}\text { Cancer Cases } \\
\text { No.(\%) }\end{array}$ & $\begin{array}{c}\text { Normal count } \\
\left(10^{9} / \mathrm{L}\right) 95 \% \\
\text { confidence interval }\end{array}$ \\
\hline$\leq 2$ & $30(25.0 \%)$ & $4.0-11$ \\
$03-\mathrm{Feb}$ & $38(31.7 \%)$ & $4.0-11$ \\
$\geq 4$ & $52(43.3 \%)$ & $4.0-11$ \\
Total & $120(100 \%)$ & $4.0-11$
\end{tabular}

95\% confidence interval 
Table 5. Serological identification of (VCA IgM ) by age groups of female patients

\begin{tabular}{lcccc}
\hline $\begin{array}{l}\text { Age groups } \\
\text { (years) }\end{array}$ & $\begin{array}{c}\text { No. of } \\
\text { cases }\end{array}$ & $\begin{array}{c}\text { VCA IgM } \\
\text { positive }\end{array}$ & $\begin{array}{c}\text { VCA IgM } \\
\text { negative }\end{array}$ & P value \\
\hline $25-\mathrm{Jul}$ & $15(25.0 \%)$ & $5(33.3 \%)$ & $10(66.7 \%)$ & \\
$26-44$ & $13(21.7 \%)$ & $6(46.2 \%)$ & $7(53.8 \%)$ & \\
$45-63$ & $18(30.0 \%)$ & $8(44.4 \%)$ & $10(55.6 \%)$ & 0.895 \\
$64-82$ & $14(23.3 \%)$ & $6(42.8 \%)$ & $8(57.1 \%)$ & \\
Total & $60(100 \%)$ & $25(41.7 \%)$ & $35(58.3 \%)$ & \\
\hline
\end{tabular}

were $64.6 \%, 53.8 \%, 55.6 \%$ and $57.1 \%$ for patients aged $7-25,26-44,10(55.6 \%)$ and 8 (57.1\%) years, respectively. No significant differences in the coefficients of variation for anti-VCA IgM were observed between males in different age groups $(P \geq 0.05)$, as shown in Table 6 .

EBNA-1 and EBNA-2 were used to perform sequential dilutions to asses if the patients were positive or negative with respect to anti-VCA IgM. The clinical results of 60 samples derived from female cancer patients undergoing chemotherapy were obtained. Serological identifications of EBNA1 and EBNA-2 were quantified and grouped by age. Females aged 7-25, 26-44, 45-63 and 64-82 years were determined to have 15 (25.0\%), 13 (21.7\%), 18 (30.0\%) and 14 (23.3\%) EBNA-1 and EBNA-2 levels, respectively. No significant differences in the serological EBNA-1 and EBNA-2 levels were detected between the various age groups ( $P$ > 0.05), as indicated in Table 7.

The presence of EBNA-1 and EBNA-2 was detected by performing sequential dilutions of positive and negative samples concerned with anti-VCA IgM. Clinical results were obtained from 60 samples that were collected from male cancer patients. Serological levels of EBNA-1 and EBNA-2 in males aged $7-25,26-44,45-63$ and $64-82$ years were found to be $15(25.0 \%), 13(21.7 \%), 18$ (30.0\%) and 14 (23.3\%) respectively. No significant differences were observed between the various age groups of male patients $(P>0.05)$.

\section{Dissection}

The current study provides an analysis of the relationship between low WBC count, which is defined as less than $4,000 / \mathrm{mm}^{3}\left(4.0 \times 10^{9}\right)$ $\mathrm{L})$, and cancer patients receiving chemotherapy;

Table 6. Serological identification of (VCA IgM) by age groups of male cases

\begin{tabular}{lcccc}
\hline $\begin{array}{l}\text { Age group } \\
\text { (years) }\end{array}$ & $\begin{array}{c}\text { Cancer cases } \\
\text { No.(\%) }\end{array}$ & $\begin{array}{c}\text { VCA IgM } \\
\text { positive }\end{array}$ & $\begin{array}{c}\text { VCA IgM } \\
\text { negative }\end{array}$ & P value \\
\hline $25-\mathrm{Jul}$ & $15(25.0 \%)$ & $7(64.6 \%)$ & $8(53.3 \%)$ & 0.942 \\
$26-44$ & $13(21.7 \%)$ & $7(53.8 \%)$ & $6(46.2 \%)$ & \\
$45-63$ & $18(30.0 \%)$ & $10(55.6 \%)$ & $8(44.4 \%)$ & \\
$64-82$ & $14(23.3 \%)$ & $8(57.1 \%)$ & $6(42.9 \%)$ & \\
Total & $60(100 \%)$ & $32(53.3 \%)$ & $28(46.7 \%)$ & \\
\hline
\end{tabular}

Table 7. Serological identification of (EBNA1,EBNA2) depending on age groups of female patients

\begin{tabular}{|c|c|c|c|c|c|c|}
\hline \multirow{2}{*}{$\begin{array}{l}\text { Age } \\
\text { groups } \\
\text { (years) }\end{array}$} & \multirow{2}{*}{$\begin{array}{c}\text { Cancer } \\
\text { cases } \\
\text { No.(\%) }\end{array}$} & \multicolumn{2}{|c|}{ ENBA 1} & \multicolumn{2}{|c|}{ EBNA 2} & \multirow[t]{2}{*}{$P$ value } \\
\hline & & positive & negative & positive & negative & \\
\hline 25-Jul & $15(25.0 \%)$ & $5(33.3)$ & $10(66.7 \%)$ & $5(33.3)$ & $10(66.7 \%)$ & 0.98 \\
\hline $26-44$ & $13(21.7 \%)$ & $6(46.2 \%)$ & $7(53.8 \%)$ & $5(38.5 \%)$ & $8(61.5 \%)$ & 0.785 \\
\hline $45-63$ & $18(30.0 \%)$ & $8(44.4 \%)$ & $10(55.6 \%)$ & $6(33.3 \%$ & $12(66.7 \%)$ & 0.366 \\
\hline $64-82$ & $14(23.3 \%)$ & $5(35.7 \%)$ & $9(64.3 \%)$ & $4(28.6 \%)$ & $10(71.4 \%)$ & 0.50 \\
\hline Total & $60(100 \%)$ & $24(40.0 \%)$ & $36(60.0 \%)$ & $20(33.3 \%)$ & $40(66.7 \%)$ & \\
\hline \multicolumn{2}{|c|}{$P$ value } & \multicolumn{2}{|c|}{0.864} & \multicolumn{2}{|c|}{0.960} & \\
\hline
\end{tabular}


Table 8. Identification of EBNA1, EBNA2 depending of age groups of male cases

\begin{tabular}{|c|c|c|c|c|c|c|}
\hline \multirow{2}{*}{$\begin{array}{l}\text { Age group } \\
\text { (years) }\end{array}$} & \multirow{2}{*}{$\begin{array}{c}\text { Cancer } \\
\text { Cases } \\
\text { No.(\%) }\end{array}$} & \multicolumn{2}{|c|}{ EBNA1 } & \multicolumn{2}{|c|}{ EBNA2 } & \multirow[t]{2}{*}{$P$ value } \\
\hline & & positive & negative & positive & negative & \\
\hline 25-Jul & $15(25.0 \%)$ & $6(40.0 \%)$ & $9(60.0 \%)$ & $4(26.7 \%)$ & $11(73.3 \%)$ & 0.3499 \\
\hline $26-44$ & $13(21.7 \%)$ & $7(53.8 \%)$ & $6(46.2 \%)$ & $6(46.2 \%)$ & $7(53.8 \%))$ & 0.783 \\
\hline $45-63$ & $18(30.0 \%)$ & $10(55.6 \%)$ & $8(44.4 \%)$ & $9(50.0 \%)$ & $9(50.0 \%)$ & 0.747 \\
\hline $64-82$ & $14(23.3 \%)$ & $7(50.0 \%)$ & $7(50.0 \%)$ & $6(42.9 \%)$ & $8(57.1 \%)$ & 0.775 \\
\hline Total & $60(100 \%)$ & $30(50.0 \%)$ & $30(50.0 \%)$ & $25(41.7 \%)$ & $35(58.3 \%)$ & \\
\hline \multicolumn{2}{|c|}{ P value } & \multicolumn{2}{|c|}{0.826} & \multicolumn{2}{|c|}{0.539} & \\
\hline
\end{tabular}

we discovered several novel findings. In our study, the highest number of cancer patients (35 patients; 29.2\%) were aged between 45 and 63 years among both males and females; this is discordant with previous findings ${ }^{44}$. Adult cancer patients with a low WBC count that are aged between 45 to 63 years remain susceptible to primary EBV infection. Additionally, 30 (25.0\%) cancer patients were between the ages of 7 and 25 years; this is in agreement with findings suggesting that infections in children are asymptomatic, but present with symptoms in infected teenagers ${ }^{45}$. The misdiagnosis of primary EBV infection in smaller and young children is attributed to atypical laboratory findings.A factor that is related to EBV infection is the cancer type. The highest number of patients from Najaf city that were included in our study suffered from breast cancer $(24$ patients; 20.0\%). Other studies have reported EBV infection in $26.37 \%$ (95\% Cl: $22-31 \%$ ) of the 44 patients included in the study ${ }^{46}$; hence, this indicates a strong statistical relationship between EBV infection and breast cancer.

In our study, EBV infected 52/120 (43.3\%) cancer patients with low WBC; the incidence rate is $\geq 4\left(4.0 \times 10^{9}\right.$ per $\left.\mathrm{L}\right)$. EBV was previously reported to be prevalent in $26.37 \%$ (95\% C.I.; $22-31 \%$ ) of the 44 included patients ${ }^{46}$. This association may be correlated with nutritional status as protein deficiencies could lead to a compromised immune system Age is one of the most important risk factors for cancer patients with low WBC count. Our study found no significant $(p>0.05)$ difference between EBV infection and low WBC in cancer patients receiving chemotherapy on the basis of gender and age. This result is in disagreement with previous findings ${ }^{48,49}$. Previous studies have shown that female cancer patients are more susceptible to infection compared to male cancer patients ${ }^{50,51}$; additionally, cancer patients receiving chemotherapy were also previously reported to temporarily suffer from a low WBC count, which returns to normal after a few days. During this period, patients have a chance of being infected by viruses. The adults patients may have reduced bone marrow, renal and hepatic function, and complication arising from other treatments.

Moreover, negative anti-EBV VCA IgM and IgG test indicates that the patient has no immunity; conversely, if a patient tests positive for anti-EBV VCA IgM antibodies and positive or negative for the VCA IgG antibody, the result is interpreted and indicates that the person has an acute infection or is at the non-specificity phase. If the anti-EBV VCA IgM antibodies test is negative and the VCA IgG test is positive, the patient is considered to have been affected by infection. This is in accordance with previous findings ${ }^{52}$.

The distribution of the EBV among cancer patients receiving chemotherapy was investigated due to immunosuppressive effects of chemotherapy. Significance was set at $P$ value $<0.05$ and the findings are in agreement with previous reports ${ }^{37,53}$. Viruses can reactivate from the latent phase when cancer patients or host undergo an immune impairment.

EBNA-1 is known as a faint multifunctional viral protein that binds with $\mathrm{EBV}^{54}$. It is the only EBV protein found in all malignant tumors associated with $\mathrm{EBV}^{55,56}$. It is important in creating and maintaining the changing state of cells while developing $\mathrm{EBV}^{57}$. EBNA-1 contains a recurrent chain of glycine and alanine residues that separates the protein into amino and carboxylic peripheral bands ${ }^{57}$. This sequence also appears to stabilize the protein and prevent its breakdown, while 
also weakening antigen processing and major histocompatibility complex (MHC)-associated antigen presentation. Consequently, CD8-cytotoxic T cells associated with CD8 are prevented from responding against HIV-infected cells ${ }^{58}$. EBNA-1 is expressed from the Qp promoter during all transition time programs ${ }^{57}$ It is the only viral protein expressed in the first latency program ${ }^{54,58}$.

EBNA-2 is one of six EBV viral nuclear proteins expressed in infected $B$ lymphocytes, a protein modulus. EBNA-2 is involved in the regulation of latent viral transcription and contributes to immortalized EBV-infected cells $s^{58,59}$. EBNA-2 acts as a conversion molecule that binds to DNA binding proteins of cell sequences, recombinant signal binding protein JK (RBP-JK) and PU.1; it also works with multiple members of the RNA polymerase transcription complex ${ }^{59}$.

\section{CONCLUSION}

Epstein-Barr virus infection has been related to a low white blood cell count in cancer patients receiving chemotherapy. No significant differences in Epstein-Barr virus infection were observed between patients in terms of age and gender and between both virus strains.

\section{ACKNOWLEDGEMENTS}

We would like to thank all the staff of laboratory of Medical City.

\section{CONFLICT OF INTEREST}

The authors declare that there is no conflict of interest.

\section{AUTHORS' CONTRIBUTION}

This work was carried out in collaboration among all authors. SJY is responsible for collecting samples and assessment each one; TAM making all official statistical analysis; HHA is responsible for reviewing the research. All authors read and approved the final manuscript.

\section{FUNDING}

None.

\section{ETHICS STATEMENT}

This work approved by ethical committee of University of Kufa.

\section{DATA AVAILABILITY}

The data that involved in this study are included in the manuscript and presented as Tables and figures.

\section{REFERENCES}

1. Maylin S, Feghoul L, Salmona M, et al. Evaluation the Architect EBV VCA IgM, VCA IgG, and EBNA-1 IgGchemiluminescent immunoassays to assess EBV serostatus prior transplantation. PubMed, J Med Virol. 2017;89(11):2003-2010. https://doi.org/10.1002/ jmv.24889

2. Tselis A, Jenson HB, eds. Epstein-Barr Virus. Taylor and Francis, New York, NY. Rickinson AB, Kieff. EpsteinBarr Virus. In Fields Virology, $5^{\text {th }}$ Edition, Knipe. 2006. https://doi.org/10.3109/9781420014280

3. Aitken C, Sengupta SK, Aedes C, Moss DJ, Sculley TB. Heterogeneity within the Epstein-Barr virus nuclear antigen 2 gene in different strains of Epstein-Barr virus. J Gen Virol. 1994;75(Pt 1):95-100. https://doi. org/10.1099/0022-1317-75-1-95

4. Tselis A, Jenson HB, eds. Epstein-Barr Virus. Taylor and Francis, New York. 2006. https://doi. org/10.3109/9781420014280

5. Rickinson $A B$, Kieff. Epstein-Barr Virus. In Fields Virology, $5^{\text {th }}$ Edition, Knipe DM and Howley PM, eds, Wolters Kluwer/Lippincott Williams \& Wilkins, Philadelphia, PA, Chapter 68B. 2007.

6. Leight ER. Sugden B. EBNA-1: a protein pivotal to latent infection by Epstein-Barr virus. Rev Med Virol. 2000;10:83-100. https://doi.org/10.1002/ (SICI)1099-1654(200003/04)10:2\%3C83::AIDRMV262\%3E3.0.CO;2-T

7. American Cancer Society website. Infections in people with cancer. www.cancer.org/treatment/treatmentsand-side-effects/physical-sideeffects/infections/ infections-in-people-with-cancer.html. Updated February 25, 2015. Accessed May 2, 2019.

8. Centers for Disease Control and Prevention website. Preventing infections in cancer patients. www.cdc. gov/cancer/preventinfections/index.htm. Updated November 28, 2018. Accessed May 2, 2019.

9. Zhang, XN, Dawson CW, He AW, Huang PC. Immune evasion strategies of the human gamma-herpesviruses: implications for viral tumorigenesis. External $J$ Med Virol. 2012;84(2):272-81. https://doi.org/10.1002/ jmv.22267

10. CDC. Epidemiologic Notes and Reports Burkitt's Lymphoma-Winchester, Virginia. MMWR. 1997;46(29):674-68.

11. CDC. Pseudo-Outbreak of Infectious MononucleosisPuerto Rico, 1990. MMWR. 1991;40(32):552-5.

12. Molyneux EM, Rochford R, Griffin B, Newton R, Jackson G, Menon G. Burkitt' slymphoma External. Lancet. 2012;379(9822):1234-1244. https:// doi.org/10.1016/S0140-6736(11)61177-X

13. Balkwill F, Mantovani A. Inflammation and cancer: back to Virchow? [see comment] Lancet. 2001;357:539545. https://doi.org/10.1016/S0140-6736(00)04046-0

14. Mantovani A, Schioppa T, Porta C, Allavena P, Sica $A$. Role of tumor-associated macrophages in 
tumor progression and invasion. Cancer Metastasis Rev. 2006;25:315-322. https://doi.org/10.1007/ s10555-006-9001-7

15. Sica A, Schioppa T, Mantovani A, Allavena P. Tumour-associated macrophages are a distinct M2 polarised population promoting tumour progression: potential targets of anti-cancer therapy. Eur J Cancer. 2006;42:717-727. https://doi.org/10.1016/j. ejca.2006.01.003

16. Thorley-Lawson DA, Geilinger K. Monoclonal antibodies against the major glycoprotein (gp350/220) of Epstein-Barr virus neutralize infectivity. Proc Natl Acad Sci USA. 1980;77:5307-5311. https://doi. org/10.1073/pnas.77.9.5307

17. Schillinger M, Kampmann M, Henninger K, Murray G, Hanselmann I, Bauer G. Variability of humoral immune response to acute Epstein-Barr virus (EBV) infection: evaluation of the significance of serological markers. Med Microbiol Lett. 1991;2:296-303.

18. Evans AS, Niederman JC, Cenabre LC, West B, Richards VA. A prospective evaluation of heterophile and Epstein-Barr virus-specific IgM antibody tests in clinical and subclinical infectious mononucleosis: Specificity and sensitivity of the tests and persistence of antibody. J Infect Dis. 1975;132:546-554. https:// doi.org/10.1093/infdis/132.5.546

19. Crawford J, Wolff DA, Culakova E, et al. First cycle risk of severe and febrile neutropenia in cancer patients receiving systemic chemotherapy: results from a prospective nationwide study. Blood. 2004;104:607a-608a https://doi.org/10.1182/blood. V104.11.2210.2210

20. Moss DJ, Burrows SR, Khanna R. EBV: immunobiology and host response. In Human Herpesviruses: Biology, Therapy and Immunoprophylaxis. 2012.

21. Maylin S, Feghoul L, Salmona M, et al.. Evaluation the Architect EBV VCA IgM, VCA IgG, and EBNA-1 IgGchemiluminescent immunoassays to assess EBV serostatus prior transplantation MMWR. 2018;46(29):674-678.

22. Yarnell JW, Patterson CC, Sweetnam PM, Lowe GD. Haemostatic/inflammatory markers predict 10 -year risk of IHD at least as well as lipids: the Caerphilly collaborative studies. [see comment] Eur Heart J. 2004;25:1049-1056. https://doi.org/10.1016/j. ehj.2004.04.011

23. Brown DW, Ford ES, Giles WH, Croft JB, Balluz LS, Mokdad AH. Associations between white blood cell count and risk for cerebrovascular disease mortality: NHANES II Mortality Study, 1976-1992. Ann Epidemiol. 2004;14:425-430. https://doi.org/10.1016/j. annepidem.2003.11.002

24. Maltoni M, Caraceni A, Brunelli C, Broeckaert B, Christakis N, Eychmueller S. Prognostic factors in advanced cancer patients: evidence-based clinical recommendations-a study by the Steering Committee of the European Association for Palliative Care. J ClinOncol. 2005;23:6240-6248. https://doi. org/10.1200/JCO.2005.06.866

25. Vidal L, Ben Dor I, Paul M, Eliakim-Raz N, Pokroy E, SoaresWeiser K, Leibovici L. Oral versus intravenous antibiotic treatment for febrile neutropenia in cancer patients.
Cochrane Database Syst Rev. 2013;(10):CD003992. https://doi.org/10.1002/14651858.CD003992.pub3

26. Chan KH, Ng MH, Seto WH, Peiris JS. Epstein-Barr virus (EBV) DNA in sera of patients with primary EBV infection. J Clin Microbiol. 2001;39:4152-4154. https:// doi.org/10.1128/JCM.39.11.4152-4154;2001

27. Preti M, Rotondo JC, Holzinger D, et al. Role of human papillomavirus infection in the etiology of vulvar cancer in Italian women. Infect Agent Cancer. 2020;15:20. PMID:32266002. https://doi.org/10.1186/s13027020-00286-8

28. Rotondo JC, Bononi I, Puozzo A, et al..Merkel Cell Carcinomas Arising in Autoimmune Disease Affected Patients Treated With Biologic Drugs, Including AntiTNF. Clin Cancer Res. 2017;23(14):3929-3934. PMID: 28174236. https://doi.org/10.1158/1078-0432.CCR16-2899

29. Luderer R, Kok M, Niesters HG, Schuurman R, de Weerdt O, Thijsen SF. Real-time Epstein-Barr virus PCR for the diagnosis of primary EBV infections and EBV reactivation. Mol Diagn. 2005;9:195-200. https://doi. org/10.1007/BF03260091

30. Fan H, Kim SC, Chima CO, et al. Epstein-Barr viral load as a marker of lymphoma in AIDS patients. J Med Virol. 2005;75:59-69. https://doi.org/10.1002/jmv.20238

31. Stevens SJ, Smits PH, Verkuijlen SA, et al. Aberrant Epstein-Barr virus persistence in HIV carriers is characterized by anti-Epstein-Barr virus IgA and high cellular viral loads with restricted transcription. AIDS. 2007;21:2141-2149. https://doi.org/10.1097/ QAD.0b013e3282eeeba0

32. Fellner MD, Durand K, Correa RM, et al. Circulating Epstein-Barr virus (EBV) in HIV-infected patients and its relation with primary brain lymphoma. Int J Infect Dis. 2007;11:172-178. https://doi.org/10.1016/j. ijid.2006.04.001

33. Ambinder RF, Lin L. Mononucleosis in the laboratory. J Infect Dis. 2005;192:1503-1504. https://doi. org/10.1086/491746

34. Culakova E, Thota R, Poniewierski MS, et al. Patterns of chemotherapy-associated toxicity and supportive care in US oncology practice: a nationwide prospective cohort study. Cancer Med. 2014;3:434-444. https:// doi.org/10.1002/cam4.200

35. Kimura $H$, Ito $Y$, Suzuki R, Nishiyama $Y$. Measuring Epstein-Barr virus (EBV) load: the significance and application for each EBV-associated disease. Rev Med Virol. 2008;18:305-319. https://doi.org/10.1002/ rmv.582

36. Jia $Y$, Wang $Y$, Chao $Y$, Jing $Y$, Sun $Z$, Luo B. Sequence analysis of the Epstein-Barr virus (EBV) BRLF1 gene in nasopharyngeal and gastric carcinomas. Virol J. 2010;7:341. https://doi.org/10.1186/1743-422X-7-341

37. http://www.ncbi.nlm.nih.gov/ BLAST (National Center for Biotechnology Information; http://www.ncbi.nlm. nih.gov/)

38. Luka J, Chase RC, Pearson G. A sensitive enzyme-linked immunosorbent assay (ELISA) against the major EBVassociated antigens. J Immunol Methods. 1984;67:145149. https://doi.org/10.1016/0022-1759(84)90093-0

39. Page last reviewed: Selected Morbidity and Mortality Weekly Report (MMWR) Articles. 2018. 
40. Sugiura $\mathrm{M}$, Imai $\mathrm{S}$, Tokunaga $\mathrm{M}$, et al. Transcriptional analysis of Epstein-Barr virus gene expression in EBVpositive gastric carcinoma: unique viral latency in the tumour cells. Br J Cancer. 1996;74:625-631. https:// doi.org/10.1038/bjc.1996.412

41. Ikuta K, Satoh Y, Hoshikawa Y, Sairenji T. Detection of Epstein-Barr virus in salivas and throat washings in healthy adults and children. Microbes Infect. 2000;2:115-120. https://doi.org/10.1016/S12864579(00)00277-X

42. Jin Y, Xie Z, Lu G, Yang S, Shen K. Characterization of variants in the promoter of BZLF1 gene of EBV in nonmalignant EBV-associated diseases in Chinese children. Virolo J. 2010;7:92. https://doi. org/10.1186/1743-422X-7-92

43. kwangheekim, eunmeehan, eungseok lee, hongseok park, insunkim, young-sikkim. Departments of Pathology, and Urology, Korea University Ansan Hospital, Ansan, Korea, and Department of Medicine, Albert Einstein College of Medicine, Bronx, NY. 2005.

44. Schmader KE, van der Horst CM, Klotman ME. Epstein-Barr virus and the elderly host. Rev Infect Dis. 1989;11:64-73. https://doi.org/10.1093/ clinids/11.1.64

45. Auwaerter PG. Infectious mononucleosis in middle age. JAMA. 1999;281:454-459. https://doi. org/10.1001/jama.281.5.454

46. Farahmand M, Monavari SH, Shoja Z, Ghaffari $\mathrm{H}$, Tavakoli M, Tavakoli A. Epstein-Barr virus and risk of breast cancer: a systematic review and metaanalysis. US National Library of Medicine National Institutes of Health. 2019;15(24):2873-2885. https:// doi.org/10.2217/fon-2019-0232

47. Weycker D, Li X, Edelsberg J, et al. Risk of febrile neutropenia in patients receiving emerging chemotherapy regimens. 2014. https://doi. org/10.1007/s00520-014-2362-5

48. Halevy J, Ash S. Infectious mononucleosis in hospitalized patients over forty years of age. Am J Med Sci. 1988;295:122-124. https://doi. org/10.1097/00000441-198802000-00006

49. Crighton M, Puppione A. Geriatric neutrophils: implications for older adults. Semin Oncol Nurs. 2006;22:3-9. https://doi.org/10.1016/j. soncn.2005.10.002
50. Balducci L, Hardy CL, Lyman GH. Hemopoiesis and aging. Cancer Treat Res. 2005;124:109-134. https:// doi.org/10.1007/0-387-23962-6_6

51. Wardwell L, Chapman-Novakofski K, Herrel S, Woods J. Nutrient intake and immune function of elderly subjects. J Am Diet Assoc. 2008;108:2005-2012. https://doi.org/10.1016/j.jada.2008.09.003

52. Wang $X$, Wang $Y$, Wu G, Chao $Y$, Sun Z, LuoB. Sequence analysis of Epstein-Barr virus EBNA-2 gene coding amino acid 148-487 in nasopharyngeal and gastric carcinomas. Virology Journal. 2012;9049. https://doi. org/10.1186/1743-422X-9-49

53. Epstein-Barr virus and its association with disease - a review of relevance to general practiceBMC Family Practice. 2019;200.

54. Humme, Siblille, et al. "The EBV nuclear antigen 1 (EBNA1) enhances B cell immortalization several thousandfold". PNAS. 2003;100(19):10989-10994. https://doi.org/10.1073/pnas.1832776100

55. Duellman Sarah J, Katie L. Thompson, Joshua J Coon, Richard R Burgess. "Phosphorylation sites of EpsteinBarr Virus EBNA1 regulate its function". J Gen Virol. 2009;90(9):2251-2259. PMID 19439552. https://doi. org/10.1099/vir.0.012260-0

56. Young Lawrence S, Alan B Rickinson. "EpsteinBarr Virus: 40 Years On". Nature Reviews Cancer. 2004;4(10):757-768. PMID 15510157. https://doi. org/10.1038/nrc1452

57. Levitskaya J, Coram M, Levitsky V, et al. "Inhibition of antigen processing by the internal repeat region of the Epstein-Barr virus nuclear antigen-1". Nature. 1995;375(6533):685-688. PMID 7540727. https://doi. org/10.1038/375685a0

58. Henkel T, Ling PD, Hayward SD, Peterson MG. "Mediation of Epstein-Barr virus EBNA2 transactivation by recombination signal-binding protein J kappa". Science. 1994;265(5168):92-95. PMID 8016657. https://doi.org/10.1126/science.8016657

59. Wu DY, Kalpana GV, Goff SP, Schubach WH. “Epstein-Barr virus nuclear protein 2 (EBNA2) binds to a component of the human SNF-SWI complex, hSNF5/Ini1". J Virol. 1996;70(9):6020-6028. PMC 190622. PMID 8709224. https://doi.org/10.1128/ JVI.70.9.6020-6028.1996 